\title{
Epidemiological status of bovine tuberculosis in the state of Rio Grande do Sul, Brazil
}

\author{
Situação epidemiológica da tuberculose bovina no Estado do \\ Rio Grande do Sul, Brasil
}

\author{
Mariana Ramos Queiroz ${ }^{1}$; Ana Cláudia Mello Groff ${ }^{2}$; Nariléia dos Santos Silva ${ }^{1}$; \\ José Henrique Hildebrand Grisi-Filho ${ }^{3}$; Marcos Amaku³ ${ }^{3}$ Ricardo Augusto Dias ${ }^{3}$; \\ Evelise Oliveira Telles ${ }^{3}$; Marcos Bryan Heinemann ${ }^{3}$; José Soares Ferreira Neto ${ }^{3}$; \\ Vitor Salvador Picão Gonçalves ${ }^{4}$; Fernando Ferreira ${ }^{3 *}$
}

\begin{abstract}
A study was conducted to determine the epidemiological status of bovine tuberculosis in the state of Rio Grande do Sul. The state was divided in seven regions, and in each of them, a pre-established number of farms was randomly sampled. In each farm, cows with age equal to or greater than 24 months were selected at random and submitted to the comparative cervical tuberculin test. The animals whose tests were inconclusive were retested with the same diagnostic procedure within a minimum interval of 60 days. In all, 9,895 animals from 1,067 farms were tested. An epidemiological questionnaire was applied in the farms in order to identify risk factors associated with bovine tuberculosis. The prevalence of infected herds in the state was $2.8 \%[1.8 ; 4.0]$ and that of infected animals was $0.7 \%[0.4 ; 1.0]$. There was a trend towards a concentration of infected herds in the northern part of the state, with a predominance of dairy and mixed herds. The risk factors associated with the condition of infected herds were being a dairy herd $(\mathrm{OR}=2.90[1.40 ; 6.13])$ and herds with 16 or more cows $(\mathrm{OR}=2.61[1.20$; 5.49]). Thus, the best strategy to be adopted by the state is the implementation of surveillance systems to detect and remediate the infected herds, preferably incorporating elements of risk-based surveillance. In addition, the state must carry out a solid action of health education so that the producers test animals for bovine tuberculosis before introducing them in their herds.
\end{abstract}

Key words: Bovine tuberculosis. Brazil. Mycobacterium bovis. Prevalence. Rio Grande do Sul. Risk factors.

\section{Resumo}

Um estudo foi realizado para determinar a situação epidemiológica da tuberculose bovina no Estado de Rio Grande do Sul. O Estado foi dividido em sete regiões e em cada uma delas foi aleatoriamente amostrado um número pré-estabelecido de propriedades. Dentro de cada propriedade, fêmeas com idade igual ou superior a 24 meses foram escolhidas aleatoriamente e submetidas ao teste tuberculínico

\footnotetext{
${ }^{1}$ Discentes, Faculdade de Medicina Veterinária e Zootecnia, Universidade de São Paulo, USP, São Paulo, SP, Brasil. E-mail: mrq. vet@gmail.com, leiavet@gmail.com

${ }^{2}$ Médica Veterinária, Secretaria da Agricultura, Pecuária, Pesca e Agronegócio do Rio Grande do Sul, SEAPA/RS, Porto Alegre, RS, Brasil. E-mail: ana-groff@agricultura.rs.gov.br

${ }^{3}$ Profs., Faculdade de Medicina Veterinária e Zootecnia, USP, São Paulo, SP, Brasil. E-mail grisi@vps.fmvz.usp.br; fernando@ vps.fmvz.usp.br; amaku@vps.fmvz.usp.br; dias@vps.fmvz.usp.br; evelise@vps.fmvz.usp.br; marcosbryan@usp.br; jsoares@ vps.fmvz.usp.br

${ }^{4}$ Prof., Faculdade de Agronomia e Medicina Veterinária, Universidade de Brasília, UnB, Brasília, DF, Brasil. E-mail: vitorspg@ unb.br

* Author for correspondence
} 
cervical comparativo. Os animais que resultaram inconclusivos foram testados novamente com o mesmo procedimento diagnóstico em intervalo mínimo de 60 dias. Ao todo foram testados 9,895 animais provenientes de 1,067 propriedades. Nas propriedades, foi aplicado um questionário epidemiológico para identificar fatores de risco associados à tuberculose bovina. A prevalência de focos no estado foi de $2.8 \%$ [1.8; 4.0$]$ e a de animais $0.7 \%$ [0.4; 1.0$]$. Houve tendência de concentração de focos na parte Norte do estado, caracterizada pelo predomínio de propriedades de leite e mistas. Os fatores de risco associados à condição de foco foram exploração leiteira $(\mathrm{OR}=2.90[1.40 ; 6.13])$ e rebanhos com 16 ou mais vacas com pelo menos 24 meses de idade ( $\mathrm{OR}=2.61[1.20 ; 5.49])$. Assim, a melhor estratégia a ser adotada pelo estado é a implementação de sistema de vigilância para deteç̧ão e saneamento dos focos, de preferência incorporando elementos de vigilância baseada em risco. Além disso, o estado deve realizar uma sólida ação de educação sanitária para que seus produtores passem a testar os animais para tuberculose bovina antes de introduzi-los em seus plantéis.

Palavras-chave: Brasil. Fatores de risco. Mycobacterium bovis. Prevalência. Rio Grande do Sul. Tuberculose bovina.

\section{Introduction}

Since 2004, Brazil has been among the world's leading exporters of beef (USDA, 2015a, 2015b). The country enjoys privileged climate and territorial conditions to occupy this leadership, but paradoxically faces challenges of continental proportions related to sanity of the flock and food security.

Human tuberculosis caused by Mycobacterium bovis is associated with occupational exposure, inhalation of aerosols, and contact with carcases. The incidence varies regionally, depending mainly on the prevalence of infected herds and on the application of preventive measures (COSIVI et al., 1998; MODA et al., 1996). As it is a zoonosis that also represents significant economic losses to the bovine livestock sector, in 2001, the Ministry of Agriculture, Livestock, and Supply instituted the National Program for the Control and Eradication of Brucellosis and Animal Tuberculosis - PNCEBT (LAGE et al., 2006). As the name indicates, the program aims at eradicating these diseases. However, the epidemiological status of tuberculosis in the country is not adequately characterized.

In Brazil, sparse data of condemnation at slaughterhouses from 1989 to 1998 pointed to a national prevalence of bovine tuberculosis of $1.3 \%$ (LAGE et al., 2006). Studies on bovine tuberculosis conducted in 12 Federal Units, which hold 69\% of the Brazilian herd, showed a prevalence of infected herds between $0.36 \%$ and $9.0 \%$, in the Federal District and São Paulo, respectively (BAHIENSE et al., 2016; BARBIERI et al., 2016; DIAS et al., 2016; GALVIS et al., 2016; GUEDES et al., 2016; LIMA et al., 2016; NÉSPOLI et al., 2016; RIBEIRO et al., 2016; ROCHA et al., 2016; SILVA et al., 2016; VELOSO et al., 2016; VENDRAME et al., 2016).

Rio Grande do Sul (RS) is the most southern state of Brazil and has environmental and cultural features that distinguish it from the rest of the country in many aspects of the production of livestock: it does not have vast territory for cattle breeding and has severe winters with consequent specificities regarding the production of fodder. Cattle breeding began in RS in the beginning of the occupation of the territory and played an important role in the formation of the "gaúcha" society.

The state holds a herd of approximately 14 million bovines, being the sixth largest in Brazil and the largest in the southern region, a region that also comprises the states of Santa Catarina and Paraná (IBGE, 2013). Epidemiological data of bovine tuberculosis in Rio Grande do Sul are scarce and do not appropriately describe the disease status in the whole territory.

Almeida et al. (1997) reported $1.33 \%$ of animals positive for tuberculin in the municipalities of Guaíba and Eldorado do Sul. Poletto et al. (2004) performed the tuberculin test in 2,119 adult bovine animals belonging to 156 dairy farms in the town 
of Passo Fundo, the largest city in the north of the state, and detected 32 positive animals (1.51\%) from 6 farms (3.84\%). Only one of these animals did not present lesions suggestive of tuberculosis at necropsy. Lucena et al. (2010) reviewed necropsy reports and results of histopathological examination performed in 6,706 bovine animals between 1964 and 2008 and reported $16.7 \%$ of lesions compatible with tuberculosis. Mazzutti et al. (2011) reported $0.2 \%$ of tuberculous lesions in cattle slaughtered between 2005 and 2010, under the state and federal inspection in RS. Martins and Maroso (2012) observed 52 animals reactive to tuberculin $(0.32 \%)$ distributed in $1 \%$ of the farms of the region of Alto Uruguai.

Thus, due to the scarcity of epidemiological data, which characterizes well bovine tuberculosis throughout the territory of Rio Grande do Sul, the objective of this study was to estimate the prevalence of infected herds and infected animals and also to identify the risk factors for the disease, in order to accurately structure the fight against tuberculosis in the state.

\section{Material and Methods}

The planning of the study was carried out in collaboration with the Ministry of Agriculture, Livestock, and Supply (MAPA), the Secretariat of Agriculture, Livestock, Fisheries, and Agribusiness of Rio Grande do Sul (SEAPA-RS) and the Collaborating Center in Animal Health, located in the Faculty of Veterinary Medicine and Zootechny (FMVZ) of the University of São Paulo (USP). The field work was carried out by technicians of SEAPA-RS, between January and September 2013.

To check for possible regional differences, both in the prevalence of tuberculosis and in the risk factors involved, the state was divided in seven regions with homogeneous characteristics. For this characterization, we took into consideration the different production systems, management practices, purposes of farming, average size of herds, and marketing system, as well as the operational capacity and logistics of the official veterinary service of the state to conduct field activities, as described by Marvulo et al. (2009).

A two-stage sampling was performed to estimate the prevalence of infected herds and infected animals in the regions and in the state. In the first stage, within each region, a pre-established number of farms with reproductive activity was randomly selected from the farm registry of SEAPA-RS. In the second stage, within each farm, a preestablished amount of reproductive cows with age equal to or greater than 24 months was randomly selected. In farms where there were distinct herds, only the predominant one, the one with the greatest economic value or considered as the main objective of production, was the target of study. This herd was defined as a group of animals kept under the same management practices, i.e. exposed to equal risk factors. The selected farms that could not be sampled for some reason were replaced by means of a new drawing. The number of selected farms per region was estimated by the formula for simple random sampling (THRUSFIELD, 2007), according to the following parameters: estimated prevalence of $20 \%, 95 \%$ confidence level, and error of $10 \%$.

For the drawing of animals within each farm, the number of bovines to be examined in order to classify the farm as focus of tuberculosis or free of disease was calculated, considering an aggregate sensitivity equal to or greater than $85 \%$ and aggregate specificity equal to or greater than $95 \%$. The individual values of sensitivity and specificity adopted were $80 \%$ and $99.5 \%$, respectively. The calculations were performed with the help of Herdacc version 3.0 software.

In a farm with up to 99 breeding cows with age equal to or greater than 24 months, 20 were examined; in farms with 100 or more, 40 were examined. Animals were always randomly selected, and those that were in the period comprised between day 15 before and day 15 after delivery were replaced in the sample. 
The animals of the sample were submitted to the comparative cervical tuberculin test, conducted in accordance with the Technical Manual of the National Program for the Control and Eradication of Brucellosis and Tuberculosis (LAGE et al., 2006). To avoid dubious test results at the end of the study, the animals whose tests were inconclusive were retested with the same diagnostic procedure within a minimum interval of 60 days. All the animals testing positive were euthanized.

For farms with up to 20 tested animals, one reactive animal was enough to classify it as a tuberculosis-infected herd. For those where 40 animals were tested, at least two reactive animals were necessary to classify the herd as infected.

For each region and also for the entire state, the prevalence of herds and animals infected with bovine tuberculosis were obtained. The prevalence of infected herds within each region was also stratified by type of farming. The calculations of apparent prevalence and respective confidence intervals were performed as recommended by Dean et al. (1994). The calculations of prevalence of infected herds and infected animals in the state and prevalence of animals within the regions were made in a weighted form (DOHOO et al., 2003). The weight of each farm in calculating the prevalence of infected herds in the state was given by.

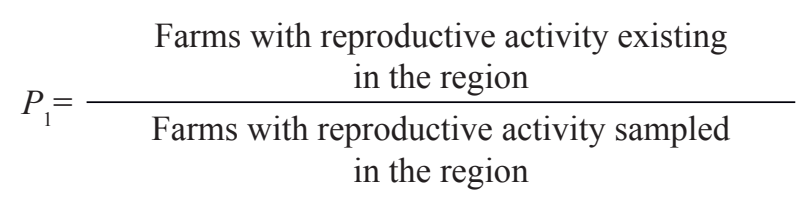

The weight of each animal in calculating the prevalence of animals in the state was given by

$$
P_{2}=\frac{\text { Cows } \geq 24 \text { months in the farm }}{\text { Cows } \geq 24 \text { months sampled in the farm }} \mathrm{X}
$$

Cows $\geq 24$ months in the region

Cows $\geq 24$ months sampled in the region
In the expression above, the first term refers to the weight of each animal in the calculation of the prevalence of infected animals within the regions. These prevalences were compared by pairwise comparisons for proportions. All calculations were performed with the package "survey" software R Core Team.

In all the farms selected for the study, a questionnaire was also applied to individualize the risk factors associated to the condition of an infected herd. The questionnaire was formulated to check the existence of exposure to classic risk factors, already described in the literature (MARANGON et al., 1998; RAMÍREZ-VILLAESCUSA et al., 2010; SKUCE et al., 2012), and others of particular regional interest. The questions addressed the following variables: type of farm (beef, dairy, or mixed); degree of agglomeration of animals (confined, semi-confined, and open range); number and breed of the animals; use of mechanical milking and artificial insemination; introduction of bovines in the last two years; presence of other animal species in the farm (domestic and wild); routine testing for bovine tuberculosis; place of slaughter of breeding animals; sharing of pastures, waterhole/ drinkers, feedstock, equipment and staff; presence of flooded areas; feeding whey to bovines, and existence of veterinary assistance.

The variables were organized to be displayed on an increasing risk scale. When necessary, reclassification of the variables was carried out. The category presenting lower risk was considered as a basis for comparison with the remaining categories. The quantitative variables were reclassified in percentiles. A first exploratory data analysis was performed (univariate analysis) to select the ones with $p \leq 0.20$ with the $\chi^{2}$ test or with the Fisher's exact test and, subsequently, subjected to logistic regression (HOSMER; LAMESHOW, 1989). The calculations were performed with the software $\mathrm{R}$ Core Team. All the information generated by field and laboratory work was inserted in a specific database and used in epidemiological analyses. 


\section{Results}

Figure 1 shows the seven regions in which the state of Rio Grande do Sul was divided in this study, and Table 1 presents the summary of the census data and the sample studied.

The prevalence of infected herds per region is presented in Table 2 and the prevalence of infected herds per type of farming is shown in Table 3.

The prevalence in animals per region is shown in Table 4. Table 5 displays the results of the univariate analysis, and Table 6 shows the final model of logistic regression for the risk factors in the state.

Figure 1. Map of the state of Rio Grande do Sul showing the seven regions of the study: 1 - South; 2 - West Frontier; 3 - Central Missions; 4 - North; 5 - Serra; 6 - Metropolitan Areas, and 7 - North Coast.

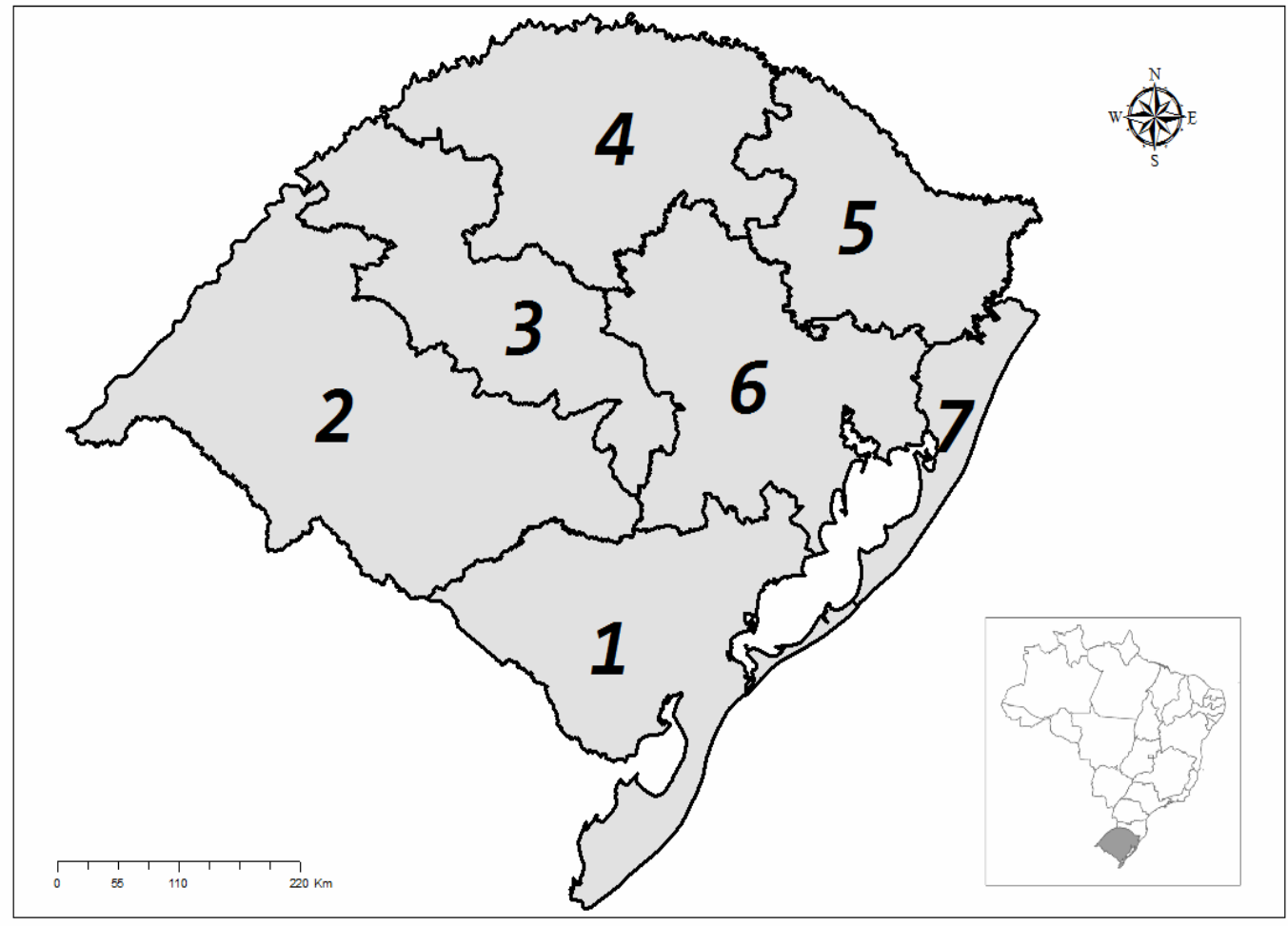

Table 1. Summary of the census of bovine herds and details of the studied sample, according to the regions of the State of Rio Grande do Sul, Brazil, 2013.

\begin{tabular}{lcccc}
\hline \multicolumn{1}{c}{ Region } & $\begin{array}{c}\text { Total of farms with } \\
\text { reproductive activity }\end{array}$ & Sampled farms & $\begin{array}{c}\text { Total of cows } \geq 24 \\
\text { months }\end{array}$ & $\begin{array}{c}\text { Cows } \geq 24 \text { months } \\
\text { sampled }\end{array}$ \\
\hline 1 - South & 35,589 & 151 & 978,737 & 1,586 \\
2- West Frontier & 34,874 & 155 & 2195,220 & 2,415 \\
3 - Central Missions & 47,483 & 150 & 937,859 & 1,603 \\
4- North & 93,888 & 155 & 899,861 & 1,211 \\
5 - Serra & 36,486 & 152 & 539,037 & 1,221 \\
6- Metropolitan Areas & 73,259 & 153 & 746,561 & 965 \\
7 - North Coast & 10,144 & 151 & 142,344 & 894 \\
\hline Total & 331,723 & 1,067 & 6439,619 & 9,895 \\
\hline
\end{tabular}


Table 2. Prevalence of infected herds with bovine tuberculosis in the state of Rio Grande do Sul, Brazil, 2013.

\begin{tabular}{lcccc}
\hline \multirow{2}{*}{ Region } & \multicolumn{2}{c}{ Farms } & \multirow{2}{*}{ Prevalence (\%) } & \multirow{2}{*}{$95 \%$ CI (\%) } \\
\cline { 2 - 3 } & Examined & Positive & 2.7 & $0.7-6.7$ \\
\hline 1 - South & 151 & 4 & 0 & $0-0.019^{*}$ \\
- West Frontier & 155 & 0 & 2.7 & $0.7-6.7$ \\
3 - Central Missions & 150 & 4 & 3.9 & $1.4-8.3$ \\
4 - North & 155 & 5 & 3.3 & $1.1-7.6$ \\
$5-$ Serra & 152 & 8 & 5.2 & $2.3-10.1$ \\
6 - Metropolitan Area & 153 & 4 & 2.7 & $0.7-6.7$ \\
7 - North Coast & 151 & 31 & 2.8 & $1.8-4.0$ \\
Rio Grande do Sul & 1,067 & 5 & & \\
\hline
\end{tabular}

*Calculation performed using the method of Monte Carlo and the beta distribution.

Table 3. Prevalence of infected herds stratified by type of enterprise in regions of the State of Rio Grande do Sul, Brazil, 2013.

\begin{tabular}{|c|c|c|c|c|c|c|}
\hline \multirow[b]{3}{*}{ Region } & \multicolumn{6}{|c|}{ Prevalence of infected herds (P) (\%) } \\
\hline & \multicolumn{2}{|c|}{ Beef } & \multicolumn{2}{|c|}{ Dairy } & \multicolumn{2}{|c|}{ Mixed } \\
\hline & $\begin{array}{c}\mathrm{P}(\%) \\
\text { (positive/ } \\
\text { examined) }\end{array}$ & $95 \%$ CI (\%) & $\begin{array}{c}\mathrm{P}(\%) \\
\text { (positive/ } \\
\text { examined) }\end{array}$ & $95 \% \mathrm{CI}(\%)$ & $\begin{array}{c}\mathrm{P}(\%) \\
\text { (positive/ } \\
\text { examined) }\end{array}$ & $95 \% \mathrm{CI}(\%)$ \\
\hline 1. South & $4.5(3 / 67)$ & $0.9-12.7$ & $1.8(1 / 57)$ & $0.04-9.6$ & $0(0 / 27)$ & $0-0.101^{*}$ \\
\hline 2. West Frontier & $0(0 / 127)$ & $0-0.019 *$ & $0(0 / 19)$ & $0-0.139 *$ & $0(0 / 9)$ & $0-0.259^{*}$ \\
\hline 3. Central Missions & $4.1(3 / 74)$ & $0.8-11.5$ & $2.5(1 / 40)$ & $0.05-13.7$ & $0(0 / 36)$ & $0-0.078^{*}$ \\
\hline 4. North & $0(0 / 10)$ & $0-0.238^{*}$ & $5.6(5 / 90)$ & $1.8-12.6$ & $1.8(1 / 55)$ & $0.04-10.0$ \\
\hline 5. Serra & $2.8(1 / 36)$ & $0.1-15.1$ & $4.2(3 / 72)$ & $0.8-11.8$ & $2.3(1 / 44)$ & $0.1-12.4$ \\
\hline 6. Metropolitan Area & $2.3(1 / 43)$ & $0.1-12.7$ & $8.6(5 / 58)$ & $2.8-19.2$ & $3.8(2 / 52)$ & $0.4-13.5$ \\
\hline 7. North Coast & $1.2(1 / 85)$ & $0.03-6.5$ & $11.8(2 / 17)$ & $1.3-37.4$ & $2.0(1 / 49)$ & $0.1-11.1$ \\
\hline
\end{tabular}

*Calculation performed using the method of Monte Carlo and the beta distribution.

Table 4. Prevalence of cows reactive to tuberculin testing by region and for the state of Rio Grande do Sul, Brazil, 2013.

\begin{tabular}{lcccc}
\hline \multirow{2}{*}{ Region } & \multicolumn{2}{c}{ Cows $\geq 24$ months } & \multirow{2}{*}{ Prevalence (\%) } & \multirow{2}{*}{$95 \%$ CI (\%) } \\
\cline { 2 - 3 } & Examined & Positive & & \\
\hline 1 - South & 1,586 & 10 & 0.7 & $0.1-2.4$ \\
- West Frontier & 2,415 & 1 & $0.02^{\text {abc }}$ & $0.000004-0.09$ \\
3 - Central Missions & 1,603 & 7 & 0.3 & $0.1-0.8$ \\
4 - North & 1,211 & 10 & $0.9^{\mathrm{a}}$ & $0.2-2.2$ \\
$5-$ Serra & 1,210 & 18 & $1.4^{\mathrm{b}}$ & $0.3-4.2$ \\
6 - Metropolitan Area & 965 & 24 & $1.3^{\mathrm{c}}$ & $0.4-3.0$ \\
7 - North Coast & 894 & 4 & 0.7 & $0.1-2.1$ \\
Rio Grande do Sul & 9,884 & 74 & 0.7 & $0.4-1.0$ \\
\hline
\end{tabular}

a, b, c different $(\mathrm{p}<0.05)$. 
Table 5. Univariate analysis of the risk factors for bovine tuberculosis in the State of Rio Grande do Sul, Brazil, 2013.

\begin{tabular}{|c|c|c|c|}
\hline Variable & Proportion of infected herds & $\%$ & P value \\
\hline $\begin{array}{l}\text { Number of cows }>2 \text { years } \\
\leq 15^{*} \\
\geq 16\end{array}$ & $\begin{array}{l}19 / 823 \\
12 / 244\end{array}$ & $\begin{array}{l}2.3 \\
4.9\end{array}$ & 0.06 \\
\hline $\begin{array}{l}\text { Farm enterprise } \\
\text { Beef /Mixed } \\
\text { Dairy }\end{array}$ & $\begin{array}{l}14 / 714 \\
17 / 353\end{array}$ & $\begin{array}{l}2.0 \\
4.8\end{array}$ & 0.02 \\
\hline $\begin{array}{l}\text { Delivers milk } \\
\text { No } \\
\text { Yes }\end{array}$ & $\begin{array}{l}15 / 813 \\
16 / 254\end{array}$ & $\begin{array}{l}1.8 \\
6.3\end{array}$ & $<0.001$ \\
\hline $\begin{array}{l}\text { Presence of wild animals } \\
\text { No } \\
\text { Yes }\end{array}$ & $\begin{array}{c}2 / 211 \\
29 / 856\end{array}$ & $\begin{array}{l}0.9 \\
3.4\end{array}$ & 0.07 \\
\hline $\begin{array}{l}\text { Presence of cabybara } \\
\text { No } \\
\text { Yes }\end{array}$ & $\begin{array}{c}22 / 869 \\
9 / 198\end{array}$ & $\begin{array}{l}2.5 \\
4.5\end{array}$ & 0.20 \\
\hline
\end{tabular}

*Third quartile.

Table 6. Final multivariate model of the risk factors for bovine tuberculosis in the state of Rio Grande do Sul, Brazil, 2013.

\begin{tabular}{lcc}
\hline Variable & Odds Ratio & $95 \%$ CI \\
\hline $\begin{array}{l}\text { Number of cows } \geq 2 \text { years } \\
\leq 15^{*}\end{array}$ & & \\
$\geq 16$ & 2.61 & $1.20-5.49$ \\
Farm enterprise & & \\
Beef /Mixed & 2.90 & $1.40-6.13$ \\
Dairy & & \\
\hline
\end{tabular}

*Third quartile.

\section{Discussion}

The prevalence of herds infected with bovine tuberculosis in Rio Grande do Sul was estimated to be $2.8 \%$ [1.8 - 4.0] (Table 2), statistically equal to the states of Bahia, Pernambuco, Paraná, Mato Grosso do Sul, Mato Grosso, Rondônia, Goiás, and the Federal District, lower than those of the states of Espírito Santo, Minas Gerais, and São Paulo, and only higher than that of the state of Santa Catarina (BAHIENSE et al., 2016; BARBIERI et al., 2016; DIAS et al., 2016; GALVIS et al., 2016; GUEDES et al., 2016; LIMA et al., 2016; NÉSPOLI et al., 2016; RIBEIRO et al., 2016; ROCHA et al., 2016; SILVA et al., 2016; VELOSO et al., 2016;
VENDRAME et al., 2016). Although in Rio Grande do Sul differences were observed only between the regions with higher and lower prevalence of infected herds (Table 2), the values indicate a higher concentration of infected herds in regions 4,5 , and 6 , located in the north of the state, in which dairy and mixed farms dominate (Tables 2 and 3).

The prevalence of animals positive to the tuberculin test in the state was estimated to be $0.7 \%$ [0.4; 1.0], ranging from $0.02 \%$ to $1.4 \%$ (Table 4 ). Although heterogeneities were detected among regions, these results follow the prevalence of infected herds, allowing the same interpretation. 
Table 6 shows that the risk factors for bovine tuberculosis in Rio Grande do Sul were being a dairy herd and having 16 or more cows in the herd.

Dairy herds are more vulnerable to tuberculosis because milk production requires the agglomeration of animals during milking, increasing the risk of transmission (BARLOW et al., 1997), since it raises the population density and, consequently, the probability of infectious contacts (ALVAREZ et al., 2012; HUMBLET et al., 2010). Dairy herds also presented higher risk for tuberculosis in New Zealand (PORPHYRE et al., 2008), United Kingdom (KAROLEMEAS et al., 2011; RAMÍREZ-VILLAESCUSA et al., 2010), and Brazil (BAHIENSE et al., 2016; BARBIERI et al., 2016; DIAS et al., 2016; GALVIS et al., 2016; ROCHA et al., 2016; SILVA et al., 2016; VELOSO et al., 2016). In addition, animals from dairy herds tend to be older than animals from beef herds, having a higher probability of being exposed to the infectious agent (HUMBLET et al., 2009).

The fact that farms with high number of animals presented a higher probability of being infected with bovine tuberculosis was also verified in the Republic of Ireland (CLEGG et al., 2012; GRIFFIN et al., 1996), United Kingdom (BESSELL et al., 2012; RAMÍREZ-VILLAESCUSA et al., 2010; REILLY; COURTENAY, 2007), New Zealand (PORPHYRE et al., 2008), and Brazil (BAHIENSE et al., 2016; DIAS et al., 2016; GALVIS et al., 2016; SILVA et al., 2016; VELOSO et al., 2016). Larger flocks have a higher replacement rate, thus increasing the risk of introduction of infected animals. The purchase of animals, in particular from risk farms, has paramount importance in the transmission of bovine tuberculosis (BESSELL et al., 2012; OLOYA et al., 2007; RAMÍREZ-VILLAESCUSA et al., 2010; REILLY; COURTENAY, 2007; SKUCE et al., 2012; TSCHOPP et al., 2009). Thus, it is plausible to assume that this variable indicates that the purchase of animals, naturally without prior testing, implies a magnification of the risk of introduction of bovine tuberculosis in a farm.

\section{Conclusion}

The state of Rio Grande do Sul has a low prevalence of bovine tuberculosis and the best strategy to adopt is the implementation of a surveillance system to detect bovine tuberculosisinfected herds to certify them as free, preferably incorporating elements of risk-based surveillance. In addition, the state must carry out a solid action of health education so that farmers test animals for bovine tuberculosis before introducing them into their herds.

\section{Acknowledgements}

The authors acknowledge the logistical and financial support from MAPA, SEAPA-RS, CNPq and FAPESP.

\section{References}

ALMEIDA, M. A. Z.; CHIMINAZZO, C.; COSTA, F. M. Ocorrência de tuberculose bovina em propriedades leiteiras nos municípios de Guaíba e Eldorado do Sul/ Rio Grande do Sul. In: CONGRESSO BRASILEIRO DE MEDICINA VETERINÁRIA, CONGRESSO ESTADUAL DE MEDICINA VETERINÁRIA, CONGRESSO DE MEDICINA VETERINÁRIA DO CONE SUL, 25., 13., 2., 1997, Porto Alegre. Anais... Porto Alegre: SOVERGS, 1997. v. 1, p. 167.

ALVAREZ, J.; PEREZ, A M.; BEZOS, J.; CASAL, C.; ROMERO, B.; RODRIGUEZ-CAMPOS, S.; SAEZLLORENTE, J. L.; DIAZ, R.; CARPINTERO, J.; DE JUAN, L.; DOMÍNGUEZ, L. Eradication of bovine tuberculosis at a herd-level in Madrid, Spain: study of within-herd transmission dynamics over a 12 year period. BMC Veterinary Research, v. 8, n. 100, p. 2-8, 2012. Available in: <http://www.biomedcentral.com/content/ pdf/1746-6148-8-100.pdf $>$. Accessed at: 05 july 2016.

BAHIENSE, L.; ÁVILA, L. N. de; BAVIA, M. E.; AMAKU, M.; DIAS, R. A.; GRISI-FILHO, J. H. H.; FERREIRA, F.; TELLES, E. O.; GONÇALVES, V. S. P.; HEINEMANN, M. B.; FERREIRA NETO, J. S. Prevalence and risk factors for bovine tuberculosis in the State of Bahia, Brazil. Semina: Ciências Agrárias, Londrina, v. 37, n. 5, p. 3549-3560, 2016. Suplemento 2.

BARBIERI, J. M.; OLIVEIRA, L. F.; DORNELES, E. M. S.; MOTA, A. L. A. A.; GONÇALVES, V. S. P.; 
MALUF, P. P.; FERREIRA NETO, J. S.; FERREIRA, F.; DIAS, R. A.; TELLES, E. O.; GRISI-FILHO, J. H. H.; HEINEMANN, M. B.; AMAKU, M.; LAGE, A. P. Epidemiological status of bovine tuberculosis in the state of Minas Gerais, Brazil, 2013. Semina: Ciências Agrárias, Londrina, v. 37, n. 5, p. 3531-3548, 2016. Suplemento 2.

BARLOW, N. D.; KEAN, J. M.; HICKLING, G.; LIVINGSTONE, P. G.; ROBSON, A. B. A simulation model for the spread of bovine tuberculosis within New Zealand cattle herds. Preventive Veterinary Medicine, Colorado, v. 32, n. 1-2, p. 57-75, 1997.

BESSELL, P. R.; ORTON, R.; WHITE, P. C. L.; HUTCHINGS, M. R.; KAO, R. R. Risk factors for bovine Tuberculosis at the national level in Great Britain. $B M C$ Veterinary Research, v. 8, p. 51, 2012. Available at: <http://www.biomedcentral.com/1746-6148/8/51>. Accessed at: 05 july 2016.

CLEGG, T. A.; BLAKE, M.; HEALY, R.; GOOD, M.; HIGGINS, I. M.; MORE, S. J. The impact of animal introductions during herd restrictions on future herdlevel bovine tuberculosis risk. Preventive Veterinary Medicine, Colorado, v. 109, n. 3-4, p. 246-257, 2012.

COSIVI, O.; GRANGE, J. M.; DABORN, C. J.; RAVIGLIONE, M. C.; FUJIKURA, T.; COUSINS, D.; ROBINSON, R. A.; HUCHZERMEYER, H. F. A. K.; DE KANTOR, I.; MESLIN, F. X. Zoonotic tuberculosis due to Mycobacterium bovis in developing countries. Emerging Infectious Diseases, v. 4, n. 1, p. 59-70, 1998.

DEAN, A. G.; DEAN, J. A.; COLOMBIER, D.; BRENDEL, K. A.; SMITH, D. C.; BURTON, A. H.; DICKER, R. C.; SULlIVAN, K.; FAGAN, R. F.; ARNER, T. G. Epi-Info, version 6: a word processing database and statistics program for epidemiology on microcomputers. Atlanta: CDC, 1994. 601 p.

DIAS, R. A.; STANOJLOVIC, F. M. U.; BELCHIOR, A. P. C.; FERREIRA, R. S.; GONÇALVES, R. C.; AGUIAR, R. S. C. B.; SOUSA, P. R.; SANTOS, A. M. A.; AMAKU, M.; FERREIRA, F.; TELLES, E. O.; GRISI-FILHO, J. H. H.; GONÇALVES, V. S. P.; HEINEMANN, M. B.; FERREIRA NETO, J. S. Prevalence and risk factors for bovine tuberculosis in the state of São Paulo, Brazil. Semina: Ciências Agrárias, Londrina, v. 37, n. 5, p. 3673-3684, 2016. Suplemento 2.

DOHOO, I.; MARTIN, W.; STRYHN, H. Veterinary epidemiologic research. Charlottetown: Atlantic Veterinary College, 2003. 706 p.

GALVIS, J. O. A.; GRISI-FILHO, J. H. H; COSTA, D.; SAID, A. L. P. R.; AMAKU, M.; DIAS, R. A.; FERREIRA, F.; GONÇALVES, V. S. P.; HEINEMANN,
M. B.; TElleS, E. O.; FERREIRA NETO, J. S. Epidemiologic characterization of bovine tuberculosis in the state of Espírito Santo, Brazil. Semina: Ciências Agrárias, Londrina, v. 37, n. 5, p. 3567-3578, 2016. Suplemento 2.

GRIFFIN, J. M.; MARTIN, S. W.; THORBURN, M. A. A case-control study on the association of selected risk factors with the occurrence of bovine tuberculosis in the Republic of Ireland. Preventive Veterinary Medicine, Colorado, v. 27, n. 34, p. 217-229, 1996.

GUEDES, I. B.; BOTTENE, I. F. N.; MONTEIRO, L. A. R. C.; LEAL FILHO, J. M.; HEINEMANN, M. B.; AMAKU, M.; GRISI-FILHO, J. H. H.; DIAS, R. A.; FERREIRA, F.; TELLES, E.O.; GONÇALVES, V. S. P.; FERREIRA NETO, J. S. Prevalence and risk factors for bovine tuberculosis in the state of Mato Grosso do Sul, Brazil. Semina: Ciências Agrárias, Londrina, v. 37, n. 5, p. 3579-3588, 2016. Suplemento 2.

HOSMER, D. W.; LEMESHOW, S. Applied logistic regression. New York: John Wiley \& Sons, 1989. 307 p.

HUMBLET,M.F.;BOSCHIROLI,M.L.;SAEGERMAN, C. Classification of worldwide bovine tuberculosis risk factors in cattle: a stratified approach. Veterinary Research, v. 40, n. 5, p. 50, 2009. Available at: <http:// www.ncbi.nlm.nih.gov/pmc/articles/PMC2710499>. Accessed at: 05 july 2016.

HUMBLET, M. F.; GILBERT, M.; GOVAERTS, M.; FAUVILLE-DUFAUX, M.; WALRAVENS, K.; SAEGERMAN, C. New assessment of bovine tuberculosis risk factors in Belgium based on nationwide molecular epidemiology. Journal of Clinical Microbiology, Barcelona, v. 48, n. 8, p. 2802-2808, 2010.

INSTITUTO BRASILEIRO DE GEOGRAFIA E ESTATÍSTICA - IBGE. Pesquisa Pecuária Municipal. Versão eletrônica. Rio de Janeiro: IBGE, 2013. Disponível em: <http://www.ibge.gov.br/home/estatistica/economia/ ppm/2013/>. Accessed at: 05 july 2016.

KAROLEMEAS, K.; MCKINLEY, T. J.; CLIFTONHADLEY, R. S.; GOODCHILD, A. V.; MITCHELL, A.; JOHNSTON, W. T.; CONLAN, A. J.; DONNELLY, C. A.; WOOD, J. L. Recurrence of bovine tuberculosis breakdowns in Great Britain: risk factors and prediction. Preventive Veterinary Medicine, Colorado, v. 102, n. 1, p. 22-29, 2011.

LAGE, A. P.; ROXO, E.; MÜLLER, E.; POESTER, F.; CAVALLÉRO, J. C. M.; FERREIRA NETO, J. S.; MOTA, P. M. P. C.; GONÇALVES, V. S. P. Programa nacional de controle e erradicação da brucelose $e$ tuberculose animal (PNCEBT). Brasília: Ministério da Agricultura, Pecuária e Abastecimento (MAPA), 2006, 184 p. (Manual técnico). 
LIMA, P. B.; NASCIMENTO, D. L.; ALMEIDA, E. C.; PONTUAL, K. A. Q.; AMAKU, M.; DIAS, R. A.; FERREIRA, F.; GONÇALVES, V. S. P.; TELLES, E. O.; GRISI-FILHO, J. H. H.; HEINEMANN, M. B.; SILVA, J. C. R.; FERREIRA NETO, J. S. Epidemiological situation of bovine tuberculosis in the state of Pernambuco, Brazil. Semina: Ciências Agrárias, Londrina, v. 37, n. 5, p. 3601-3610, 2016. Suplemento 2.

LUCENA, R. B.; PIEREZAN, F.; KOMMERS, G. D.; IRIGOYEN, L. F.; FIGHERA, R. A.; BARROS, C. S. L. Doenças de bovinos no Sul do Brasil: 6.706 casos. Pesquisa Veterinária Brasileira, Seropédica, v. 30, n. 5, p. 428-438, 2010.

MARANGON, S.; MARTINI, M.; DALLA POZZA, M.; FERREIRA NETO, J. S. A case-control study on bovine tuberculosis in the Veneto region, Italy. Preventive Veterinary Medicine, Colorado, v. 34, n. 2, p. 87-95, 1998.

MARTINS, L. L.; MAROSO, M. T. D. Ocorrência de tuberculose e brucelose em rebanhos bovinos da região do Alto do Uruguai - RS nos anos 2010, 2011 e $1^{\circ}$ semestre de 2012. Porto Alegre: Secretaria Estadual de Agricultura, Pecuária e Agronegócio, dez. 2012. (Informativo Técnico $\mathrm{n}^{\circ} 12 /$ ano 3). Disponível em: $<$ https://www.google.com.br/url?sa $=\mathrm{t} \& \mathrm{rct}=\mathrm{j} \& \mathrm{q}=\&$ esrc $=$ s\&source $=$ web $\& \mathrm{~cd}=1 \&$ ved $=0 \mathrm{CB} 0 \mathrm{QFjAAahUKEwito}$ NK_qZ3JAhUFVh4KHUbdD20\&url=http $\% 3 \mathrm{~A} \% 2 \mathrm{~F} \% 2$ Fwww.dda.agricultura.rs.gov.br\%2Fajax\%2Fdownload. php\%3FqArquivo\%3D20130225113925informativo tecnico_dezembro__n_12.pdf\&usg=AFQjCNEH2oY gsYeSw2hzYJ9MU-_eEXCo5A\&sig2=df01-kwsBRMA5h-uifnxw\&cad=rja $>$. > . Accessed at: 05 july 2016.

MARVULO, M. F. V.; FERREIRA, F.; DIAS, R. A.; AMAKU, M.; GROFF, A. C. M.; GONÇALVES, V. S. P.; FIGUEIREDO, V. C. F.; LÔBO, J. R.; FERREIRA NETO, J. S. Situação epidemiológica da brucelose bovina no Estado do Rio Grande do Sul. Arquivo Brasileiro de Medicina Veterinária e Zootecnia, Belo Horizonte, v. 61, p. 93-102, 2009. Suplemento 1.

MAZZUTTI, K. C.; DICKEL, E. L.; VIDOR, A. C. M.; CERESER, N. D.; PAN, K. A. Ocorrência da tuberculose em bovinos abatidos no Rio Grande do Sul - 2005 a 2010. In: CONGRESSO BRASILEIRO DE MEDICINA VETERINÁRIA - CONBRAVET, 38., 2011, Florianópolis. Anais... Florianópolis: Revista de Ciências Agroveterinárias, 2011. Disponível em: <http://sovergs. com.br/site/38conbravet/resumos/79.pdf $>$. Accessed at: 05 july 2016.

MODA, G.; DABORN, C. J.; GRANGE, J. M.; COSIVI, $\mathrm{O}$ The zoonotic importance of Mycobacterium bovis. Tubercle and Lung Disease, Berlin, v. 77, n. 2, p. 103108, 1996.
NÉSPOLI, J. M. B.; NEGREIROS, R. L.; AMAKU, M.; DIAS, R. A.; FERREIRA, F.; TELLES, E. O.; HEINEMANN, M. B.; GRISI-FILHO, J. H. H.; GONÇALVES, V. S. P.; FERREIRA NETO, J. S. Epidemiological situation of bovine tuberculosis in the state of Mato Grosso, Brazil. Semina: Ciências Agrárias, Londrina, v. 37, n. 5, p. 3589-3600, 2016. Suplemento 2.

OLOYA, J.; MUMA, J. B.; OPUDA-ASIBO, J.; DJØNNE, B.; KAZWALA, R.; SKJERVE, E. Risk factors for herd-level bovine-tuberculosis seropositivity in transhumant cattle in Uganda. Preventive Veterinary Medicine, Colorado, v. 80, n. 4, p. 318-329, 2007.

POLETTO, R.; KREUTZ, L. C.; GONZALES, J. C.; BARCELLOS, L. J. G. Prevalência de tuberculose, brucelose e infecções víricas em bovinos leiteiros do município de Passo Fundo, RS. Ciência Rural, Santa Maria, v. 34, n. 2, p. 595-598, 2004.

PORPHYRE, T.; STEVENSON, M. A.; MCKENZIE, J. Risk factors for bovine tuberculosis in New Zealand cattle farms and their relationship with possum control strategies. Preventive Veterinary Medicine, Colorado, v. 86, n. 1-2, p. 93-106, 2008.

RAMÍREZ-VILLAESCUSA, A. M.; MEDLEY, G. F.; MASON, S.; GREEN, L. E. Risk factors for herd breakdown with bovine tuberculosis in 148 cattle herds in the south west of England. Preventive Veterinary Medicine, Colorado, v. 95, n. 3-4, p. 224-230, 2010.

REILLY, L. A.; COURTENAY, O. Husbandry practices, badger sett density and habitat composition as risk factors for transient and persistent bovine tuberculosis on UK cattle farms. Preventive Veterinary Medicine, Colorado, v. 80, n. 2-3, p. 129-142, 2007.

RIBEIRO, L. A.; GONÇALVES, V. S. P.; FRANCISCO, P. F. C.; MOTA, A. L. A. A.; NASCIMENTO, G. T.; LICURGO, J. B.; FERREIRA, F.; GRISI-FILHO, J. H. H.; FERREIRA NETO, J. S.; AMAKU, M.; DIAS, R. A.; TELLES, E. O.; HEINEMANN, M. B.; BORGES, J. R. J. Epidemiological status of bovine tuberculosis in the Federal District of Brazil. Semina: Ciências Agrárias, Londrina, v. 37, n. 5, p. 3561-3566, 2016. Suplemento 2.

ROCHA, W. V.; JAYME, V. S.; MOTA, A. L. A. A.; BRITO, W. M. E. D; PIRES, G. R. C; GRISI-FILHO, J. H. H; DIAS, R. A.; AMAKU, M.; TELLES, E. O.; HEINEMANN, M. B.; FERREIRA, F.; FERREIRA NETO, J. S.; GONÇALVES, V. S. P. Prevalence and herd-level risk factors of bovine tuberculosis in the State of Goiás, Brazil. Semina: Ciências Agrárias, Londrina, v. 37, n. 5, p. 3625-3628, 2016. Suplemento 2.

SILVA, M. C. P.; GONÇALVES, V. S. P.; MOTA, A. L. A. A.; KOLODA, M.; FERREIRA NETO, J. S.; GRISIFILHO, J. H. H; DIAS, R. A.; AMAKU, M.; TELLES, 
E. O.; FERREIRA, F.; HEINEMANN, M. B.; ALFIERI, A. A.; MULLER, E. E. Prevalence and herd-level risk factors for bovine tuberculosis in the state of Paraná, Brazil. Semina: Ciências Agrárias, Londrina, v. 37, n. 5, p. 3611-3624, 2016. Suplemento 2.

SKUCE, R. A.; ALLEN, A. R.; MCDOWELL, S. W. J. Herd-level risk factors for bovine tuberculosis: a literature review. Veterinary Medicine International, v. 2012, Article ID 621210, p. 1-10, 2012. Available at: $<$ http://www.hindawi.com/journals/vmi/2012/621210/ abs/>. >. Accessed at: 05 july 2016.

THRUSFIELD, M. Veterinary epidemiology. $3^{\text {th }}$ ed. Cambridge: Blackwell Science, 2007. 610 p.

TSCHOPP, R.; SCHELLING, E.; HATTENDORF, J.; ASEFFA, A.; ZINSSTAG, J. Risk factors of bovine tuberculosis in cattle in rural livestock production systems of Ethiopia. Preventive Veterinary Medicine, Colorado, v. 89, n. 3-4, p. 205-211, 2009.

UNITED STATES DEPARTMENT OF AGRICULTURE - USDA. Economic Research Service. Washington: USDA, 2015a. Available at: <http://www.ers.usda.gov/ topics/international-markets-trade/countries-regions/ brazil/trade.aspx\#livestock>. Accessed at: 05 july 2016. - United States Department of Agriculture, Foreign Agricultural Service - Livestock and Poultry: World Markets and Trade. Washington: USDA, apr. 2015 b.

VElOSO, F. P.; BAUMGARTEN, K. D.; MOTA, A. L. A. A.; FERREIRA, F.; FERREIRA NETO, J. S.; GRISI-FILHO, J. H. H.; DIAS, R. A.; AMAKU, M.; TELLES, E. O.; HEINEMANN, M. B.; GONÇALVES, V. S. P. Prevalence and herd-level risk factors of bovine tuberculosis in the State of Santa Catarina, Brazil. Semina: Ciências Agrárias, Londrina, v. 37, n. 5, p. 3659-3672, 2016. Suplemento 2.

VENDRAME, F. B.; AMAKU, M.; FERREIRA, F.; TELLES, E. O.; GRISI-FILHO, J. H. H.; GONÇALVES, V. S. P.; HEINEMANN, M. B.; FERREIRA NETO, J. S.; DIAS, R. A. Epidemiologic characterization of bovine tuberculosis in the State of Rondônia, Brazil. Semina: Ciências Agrárias, Londrina, v. 37, n. 5, p. 3639-3646, 2016. Suplemento 2. 
